\title{
An Analysis of the Linkage of Stocks between China and Countries along the Belt and Road
}

\author{
Wenbo Du \\ International Business School \\ Yunnan University of Finance and Economics \\ Kunming, China \\ 122894558@qq.com \\ Yaxian $\mathrm{Lu}^{*}$ \\ International Business School \\ Yunnan University of Finance and Economics
}

Kunming, China
980312863@qq.com

Xiaojun Yao

School of Economics

Anhui University

Hefei, China

jx_yaoxiaojun@163.com

\begin{abstract}
This article has conducted an in-depth study on the linkage between China and the daily returns of the stock markets of 17 countries from Southeast Asia, South Asia, West Asia, North Africa, and Central and Eastern Europe. Based on the stock market indices of 18 countries including the Shanghai Composite Index, the Prague Composite Index, the Egyptian CMA Index, and the Budapest Stock Market Index, the article uses the natural logarithm to calculate the daily returns of the country's stock indexes. Through the statistical descriptive test and ADF test of the daily returns of stock indexes in 18 countries, the daily yield ratio of the Shanghai stock index is co-integrated with other countries, Granger causality test, and finally the prediction error variance decomposition is performed. The conclusion is: The Shanghai stock market's response rate to the Thai stock market's return has been at a relatively high level, followed by Egypt, Indonesia, Turkey and other countries, while Russia's impact on China's stock market has the smallest impact.
\end{abstract}

Keywords-linkage; The Belt and Road; stock index; co-integration test; granger causality test

\section{INTRODUCTION}

Since the "The Belt and Road" initiative was proposed, Chinese scholars have strengthened their research on China's financial linkages with countries along The Belt and Road. From the existing literature, most scholars focus their research on the linkage between the stocks of China and Europe, the United States, Japan, and other developed countries. Forbes [1] analyzed the role of the real economy and financial linkages between the US stock market and other 40 countries during the period 1986-2000,finding that trade flows, especially imports, and bilateral bank lending have a clear linkage to the stock market. Bonfiglioli and Favero [2] studied the situation of the stock market in the United States and Germany, confirming that there is a short-term financial contagion relationship between the stock markets of the two countries and there is no interdependence in the long term. Ehrmannetal [3]. analyzed 450 industrial stocks from the industrial level to explain the financial contagion of the US financial crisis in
2008 to other countries. Wang [4] conducted a coherent analysis of the linkages between Shanghai, Shenzhen, and Hong Kong stock markets. They pointed out that the strengths and weaknesses of the three stock markets in different periods determine the order in which they compete in the international financial center. Stark C [5] analyzed the relationship between ASEAN-5 and China, the United States, and Japan from 2000 to 2009 and found that China and Korea have strong correlations with ASEAN-5, and Japan's relevance to these countries is relatively weak. Madaleno and Pinho [6] used the Morlet wavelet transform to study the linkage of the stock markets of the United Kingdom, the United States, Japan, and Brazil, and divided the time periods according to the major political and economic events in the world. On the one hand, his research has drawn the conclusion that the relations between the stock markets of the four countries are more objective. On the other hand, it also confirms the innovativeness and effectiveness of the wavelet analysis method in the study of stock market linkage.

The above documents show that, first, the linkage of stocks between China and other countries has been further strengthened. Second, when discussing the linkage of stocks between China and the world market, stocks between China and the developed countries of Europe, the United States, and Japan is over-strengthened, insteadly, linkage between China and the developing countries is ignored. Based on these, this article starts from the background of the "The Belt and Road "Initiative and focuses on the study of the linkages between the countries along the "One Belt and One Road", which will play a positive role in promoting better understanding of the financial cooperation of countries along The Belt and Road.

\section{THE INTRINSIC MECHANISM OF STOCK MARKET LINKAGE}

The main reasons for the linkage of the stock market are mainly due to fundamental factors and behavioral factors. 


\section{A. Fundamental Factors}

When analyzing the fundamentals referring to the company's operations and basic information, we must start with the investment value and the price of the stocks. We must consider macroeconomic factors, such as national policies and regulations, as well as microeconomic factors. Operating conditions refer to the current operating conditions and operating results of the company and will have a positive or negative impact on the stock price. According to the rational person hypothesis, companies should get the greatest operating results at the lowest cost. The basic information is the financial status of the business operations, the structure of human resources, the price-earnings ratio, the market share, and the stock price. Basic information is of practical reference significance for analyzing operating results and predicting future cash flows. For rational investors, they generally select stocks that are in good operating condition and are basically oriented towards good stocks.

\section{B. Behavioral Factors}

The behavioral factors of investors mainly refer to the impact of investors behaviors on the volatility of stock prices. Behavioral finance theory holds that the market price of stocks is not determined solely by the intrinsic value of stocks, but is also influenced to a great extent by the behavior of investors, that is, investor psychology and behavior have a significant impact on price decisions and changes in the stock market. It is a theory corresponding to the effective market hypothesis, whose main content can be divided into arbitrage restrictions and psychology. The theory holds that: First, investors would make some mistakes due to their limited ration. Secondly, in the vast majority of times, rational and limited rational investors in the stock market are all working. Investors divided into rational investors and irrational investors make rational or irrational decisions based on limited information when making investment decisions. In the effective market, irrational investors may choose stocks whose value has been overestimated and whose fundamentals are relatively poor, and adopt a portfolio investment strategy, which is also an important factor causing instability in the capital market. Rational investors are able to grasp the fundamental situation, make horizontal and vertical comparisons of the stock market and dig out industries with better prospects. In the effective market, there are far more rational investors than non-rational investors. In the study of the linkage effect of stock market, there are mainly two factors attributed to behavioral economics: the linkage of investor preferences and the linkage of Sheep-Flock Effect .

\section{1) Investor preferences}

Under the condition of limited information, investors will use their limited resources to analyze and select their preferred plates and stocks according to their own information and areas they are familiar with. For risk-biased investors, they generally choose stocks with higher $\mathrm{P} / \mathrm{E}$ ratios, higher returns, and higher risks. On the contrary, risk-averse investors generally prefer large-cap blue-chip stocks, lower $\mathrm{P} / \mathrm{E}$ ratios, and risks. Relatively controllable, the return rate will generally be lower, and diversification of investment. When the investor's preference for a certain class of stocks or markets becomes main stream, the linkage effect of the stock market will appear.

\section{2) Sheep-Flock Effect}

In reality, investors generally make investment decisions based on macroeconomic policies, news reports, and the influence of the surrounding investors, which has led to the Sheep-Flock Effect. When this behavior develops into the mainstream in the market, it evolves into a linkage of the stock market. Under the condition of limited information, investors' blindly following the trend and chasing and selling will cause huge fluctuations in the stock market.

\section{SAMPLE DATA SELECTION}

At present, there are 64 countries along "The Belt and Road". In order to comprehensively demonstrate the linkage and their structural characteristics between China and the countries along "The Belt and Road" stock market, this paper selects 18 countries mainly coming from Southeast Asia, South Asia, West Asia, North Africa, and Central and Eastern Europe based on the availability of data. The stock market indices of these 18 countries are selected to reflect the trend of capital markets in these countries. The following table shows the indices and their acronyms for the selected countries. See Table 1 for details. All data comes from the Wind database.

TABLE I.

STOCK MARKET INDEX

\begin{tabular}{|c|c|c|}
\hline Stock market index & Countries & Abbreviation \\
\hline China Shanghai Composite Index & China & $\mathrm{CH}$ \\
\hline Prague Composite Index & Czech Republic & $\mathrm{CZ}$ \\
\hline Egyptian CMA Index & Egypt & EG \\
\hline Budapest Stock Market Index & Hungary & $\mathrm{HU}$ \\
\hline Mumbai SENSEX30 Index & India & $\mathrm{IN}$ \\
\hline Jakarta Composite Index & Indonesia & $\mathrm{ID}$ \\
\hline Israel TA100 Index & Israel & $\mathrm{IL}$ \\
\hline Beirut 100 Index & Lebanese & $\mathrm{LB}$ \\
\hline FTSE Kuala Lumpur Composite Index & Malaysia & $\mathrm{MY}$ \\
\hline
\end{tabular}




\begin{tabular}{|c|c|c|}
\hline Manila Composite Index & Philippines & PH \\
\hline Warsaw WIG Index & Poland & PL \\
\hline Russian stock index & Russia & RU \\
\hline Saudi Arabian Stock Composite Index & Saudi Arabia & SA \\
\hline FTSE Singapore STI Index & Singapore & SG \\
\hline Thailand Composite Index & Thailand & TH \\
\hline Istanbul ISE 100 Index & Turkey & AE \\
\hline UAE ADX Composite Index & United Arab Emirates & VN \\
\hline Ho Chi Minh Index & Vietnam & \\
\hline
\end{tabular}

The research data in this paper is the closing price of the index after the restoration of rights from January 4, 2017 to April 17, 2018. Because each stock market does not always open at the same time because of different holidays, this article eliminates the data that each stock market does not open on the same day so that the trading dates of various stock indexes can be unified. The daily return rate of the stock index is calculated using the natural logarithm form, and its calculation formula is:

$\mathrm{R}_{\mathrm{i}, \mathrm{t}}=100 \operatorname{Ln} \frac{\mathrm{P}_{\mathrm{i}, t}}{\mathrm{P}_{\mathrm{i}, \mathrm{t}-1}} \mathrm{i}(1,2, \ldots, 18)$

Among them, $\mathrm{R}^{\mathrm{i}, \mathrm{t}}$ denotes the closing price of the $\mathrm{i}$-th stock market at the time of day $\mathrm{t}$.
Source: Wind database.

\section{EMPIRICAL TEST}

\section{A. Descriptive Analysis of Sample Data}

A preliminary statistical test was conducted on the yield data of each stock market, and the descriptive analysis results of Table 2 were obtained. From the table, it can be found that in the 18 stock market index gains, Hungary, the Philippines, Russia, Saudi Arabia, Turkey, UAE and other countries appear right-biased, and the remaining countries are left-biased. The kurtosis of all stock index gains is greater than 3, indicating that all of them have "spike" characteristics; from the Jarque-Bera test, it is not difficult to see that most countries' stock returns do not follow the assumption of normal distribution (Except India, Indonesia, Russia) ; ADF test shows that there are no unit roots in the sequence and they are all stationary sequences.

TABLE II. Descriptive Test Results of 18 Stock Market Returns Alon the Belt ANd RoAd

\begin{tabular}{|c|c|c|c|c|c|c|c|c|}
\hline Countries & Mean & Maximum & Minim & $\begin{array}{l}\text { Standard } \\
\text { deviation }\end{array}$ & Skewness & Kurtosis & Jarque-Bera & ADF Test \\
\hline $\mathrm{CH}$ & -0.08 & 1.35 & -3.41 & 0.69 & -1.34 & 7.78 & $109.00^{* * *}$ & $-10.13 * * *$ \\
\hline$C Z$ & 0.087 & 1.87 & -2.13 & 0.60 & -0.03 & 5.09 & $15.95 * * *$ & $-9.314 * * *$ \\
\hline$E G$ & 0.21 & 3.59 & -3.26 & 0.97 & -0.16 & 5.37 & $20.77 * * *$ & $-5.16^{* * * *}$ \\
\hline$H U$ & 0.014 & 3.92 & -2.49 & 1.07 & 0.15 & 4.65 & $10.18^{* * *}$ & $-9.851 * * *$ \\
\hline$I N$ & 0.011 & 1.33 & -1.63 & 0.58 & -0.26 & 3.19 & 1.13 & $-7.19 * * *$ \\
\hline$I D$ & 0.026 & 3.35 & -2.05 & 0.67 & -0.37 & 3.35 & 2.42 & $-6.65 * * *$ \\
\hline$I L$ & 0.129 & 1.47 & -2.3 & 0.62 & -0.36 & 4.44 & $9.44 * * *$ & $-8.79 * * *$ \\
\hline$L B$ & -0.002 & 1.38 & -2.05 & 0.54 & -0.47 & 5.23 & $21.25 * * *$ & $-3.46 * * *$ \\
\hline$M Y$ & 0.01 & 1.33 & -2.22 & 0.51 & -1.17 & 8.34 & $123.28 * * *$ & $-8.40 * * *$ \\
\hline$P H$ & -0.043 & 2.67 & -2.16 & 0.85 & 0.34 & 4.14 & $6.39 * *$ & $-6.78 * * *$ \\
\hline$P L$ & -0.05 & 2.28 & -3.39 & 0.94 & -0.17 & 4.32 & $6.79 * *$ & $-7.39 * * *$ \\
\hline$R U$ & 0.087 & 3.76 & -2.73 & 1.19 & 0.18 & 3.44 & 1.18 & $-5.29 * * *$ \\
\hline$S A$ & -0.076 & 5.35 & -2.62 & 0.88 & 1.96 & 17.32 & $798.64 * * *$ & $-6.38 * * *$ \\
\hline$S G$ & -0.06 & 1.59 & -2.22 & 0.70 & -0.35 & 3.91 & $4.73 *$ & $-6.54 * * *$ \\
\hline$T H$ & 0.017 & 0.98 & -2.31 & 0.49 & -1.42 & 7.67 & $108.38 * * *$ & $-6.65 * * *$ \\
\hline$T R$ & 0.203 & 4.07 & -2.64 & 1.05 & 0.27 & 4.38 & $8.04 * * *$ & $-7.19 * * *$ \\
\hline
\end{tabular}




\begin{tabular}{|l|l|l|l|l|l|l|l|l|}
\hline $\boldsymbol{A} \boldsymbol{E}$ & 0.013 & 2.43 & -1.88 & 0.66 & 0.13 & 4.85 & $12.65 * * *$ & $-5.42^{* * *}$ \\
\hline $\boldsymbol{V N}$ & 0.172 & 2.82 & -3.60 & 0.90 & -1.072 & 7.86 & $102.35^{* * *}$ & $-13.67 * * *$ \\
\hline
\end{tabular}

Note: "***", "**" and $" * "$ are significant at the $1 \%, 5 \%$, and $10 \%$ levels, respectively; ADF tests do not include intercept and trend items.

\section{B. Cointegration test:}

The OLS returns of other countries to the Index are given in the table below: daily returns of the Shanghai Stock Exchange

TABLE III. The Ols Returns of Other COUNTRIES To THE DAILy RETURNS OF THE SHANGHAI STOCK EXCHANGE INEDX

\begin{tabular}{|c|c|c|c|c|c|c|c|c|c|}
\hline & CZ1 & EG1 & HU1 & IN1 & ID1 & IL1 & LB1 & MY1 & PH1 \\
\hline$t$ & 2.130 & 1.77 & 1.89 & 2.95 & 2.51 & 2.91 & 1.40 & 1.83 & 0.25 \\
\hline \multirow[t]{2}{*}{$P$} & 0.036 & 0.080 & 0.062 & 0.004 & 0.014 & 0.005 & 0.167 & 0.071 & 0.806 \\
\hline & PL1 & RU1 & SA1 & SG1 & TH1 & TR1 & AE1 & VN1 & \\
\hline$t$ & 3.68 & 2.30 & 1.88 & 5.07 & 1.94 & 1.79 & 1.03 & 2.12 & \\
\hline$P$ & 0.000 & 0.024 & 0.063 & 0.000 & 0.056 & 0.078 & 0.307 & 0.037 & \\
\hline
\end{tabular}

From the above table, it can be concluded that in addition to Lebanon, the Philippines, and the UAE, several other market stock indexes can pass the cointegration test at a confidence level of $1 \%$ to $10 \%$.
In order to determine that the above cointegration relationship does exist, it is necessary to continue the ADF stationarity test for the residuals corresponding to the OLS regression above. If the corresponding residual term is stable, cointegration does exist.

TABLE IV.

ADF STATIONARITY TEST FOR THE RESDUALS

\begin{tabular}{|c|c|c|c|c|c|c|c|c|c|c|c|c|c|}
\hline & CZ1 & HU1 & IN1 & ID1 & IL1 & MY1 & PL1 & RU1 & SA1 & SG1 & TH1 & TR1 & VN1 \\
\hline $\boldsymbol{t}$ & -10.24 & -10.18 & -9.42 & -8.27 & -9.72 & -10.70 & -9.81 & -8.97 & -10.57 & -8.81 & -8.47 & -9.37 & -12.43 \\
\hline $\boldsymbol{p}$ & 0.0000 & 0.0000 & 0.0000 & 0.0000 & 0.0000 & 0.0001 & 0.0000 & $\begin{array}{c}0.000 \\
0\end{array}$ & $\begin{array}{c}0.000 \\
0\end{array}$ & 0.0000 & 0.0000 & 0.0000 & 0.0001 \\
\hline
\end{tabular}

From the above table, it can be seen that the residual value of the stock market in each country passed the ADF test with a confidence interval of $1 \%$ to $10 \%$. Therefore, $\mathrm{CH} 1$ does indeed have a co-integration relationship with CZ1, EG1, HU1, IN1, ID1, IL1, and the like.

A. Granger causality test:

TABLE V

GRANGER CAUSALITY TEST OF CHINA AND OTHER COUNTRIES

\begin{tabular}{|c|c|c|c|}
\hline & & $\mathbf{F}$ & $\mathbf{P}$ \\
\hline \multirow[t]{2}{*}{$\mathrm{CH}$ and $\mathrm{CZ}$} & $\mathrm{CH} 1$ is not Granger Cause of $\mathrm{CZ} 1$ & 1.8846 & 0.1586 \\
\hline & $\mathrm{CZ1}$ is not Granger Cause of $\mathrm{CH} 1$ & 1.2177 & 0.3013 \\
\hline \multirow[t]{2}{*}{$C H$ and $E G$} & EG1 is not Granger Cause of CH1 & 0.9703 & 0.3834 \\
\hline & $\mathrm{CH} 1$ is not Granger Cause of EG1 & 0.0023 & 0.9977 \\
\hline \multirow[t]{2}{*}{$\mathrm{CH}$ and $\mathrm{HU}$} & HU1 is not Granger Cause of $\mathrm{CH} 1$ & 1.3019 & 0.2777 \\
\hline & $\mathrm{CH} 1$ is not Granger Cause of HU1 & 0.0829 & 0.9205 \\
\hline \multirow[t]{2}{*}{ CH and IN } & IN1 is not Granger Cause of CH1 & 0.1134 & 0.8930 \\
\hline & $\mathrm{CH} 1$ is not Granger Cause of IN1 & 1.6814 & 0.1926 \\
\hline \multirow[t]{2}{*}{$C H$ and ID } & ID1 is not Granger Cause of $\mathrm{CH} 1$ & 2.4468 & 0.0930 \\
\hline & $\mathrm{CH} 1$ is not Granger Cause of ID1 & 1.03253 & 0.3608 \\
\hline
\end{tabular}




\begin{tabular}{|c|c|c|c|}
\hline \multirow[t]{2}{*}{ CH and IL } & IL1 is not Granger Cause of $\mathrm{CH} 1$ & 3.8139 & 0.0262 \\
\hline & $\mathrm{CH} 1$ is not Granger Cause of IL1 & 0.3942 & 0.6755 \\
\hline \multirow[t]{2}{*}{$C H$ and $M Y$} & MY1 is not Granger Cause of CH1 & 1.2428 & 0.2941 \\
\hline & $\mathrm{CH} 1$ is not Granger Cause of MY1 & 3.7746 & 0.0271 \\
\hline \multirow[t]{2}{*}{$\mathrm{CH}$ and $\mathrm{PL}$} & PL1 is not Granger Cause of $\mathrm{CH} 1$ & 1.7635 & 0.1780 \\
\hline & $\mathrm{CH} 1$ is not Granger Cause of PL1 & 1.4773 & 0.2344 \\
\hline \multirow[t]{2}{*}{$\mathrm{CH}$ and $\mathrm{RU}$} & CRU1 is not Granger Cause of $\mathrm{CH} 1$ & 0.2723 & 0.7624 \\
\hline & $\mathrm{CH} 1$ is not Granger Cause of RU1 & 1.1818 & 0.3120 \\
\hline \multirow[t]{2}{*}{$C H$ and $S A$} & SA1 is not Granger Cause of $\mathrm{CH} 1$ & 0.5351 & 0.5877 \\
\hline & $\mathrm{CH} 1$ is not Granger Cause of SA1 & 0.8165 & 0.4456 \\
\hline \multirow[t]{2}{*}{$C H$ and $S G$} & SG1 is not Granger Cause of $\mathrm{CH} 1$ & 4.1345 & 0.0196 \\
\hline & $\mathrm{CH} 1$ is not Granger Cause of SG1 & 2.4518 & 0.0926 \\
\hline \multirow[t]{2}{*}{$\mathrm{CH}$ and $\mathrm{TH}$} & $\mathrm{TH} 1$ is not Granger Cause of $\mathrm{CH} 1$ & 3.5488 & 0.0334 \\
\hline & $\mathrm{CH} 1$ is not Granger Cause of TH1 & 1.0188 & 0.3656 \\
\hline \multirow[t]{2}{*}{$C H$ and $T R$} & TR1 is not Granger Cause of $\mathrm{CH} 1$ & 2.2402 & 0.1131 \\
\hline & $\mathrm{CH} 1$ is not Granger Cause of TR1 & 1.1428 & 0.3241 \\
\hline \multirow[t]{2}{*}{$C H$ and $V N$} & VN1 is not Granger Cause of $\mathrm{CH} 1$ & 0.1556 & 0.8562 \\
\hline & $\mathrm{CH} 1$ is not Granger Cause of VN1 & 0.1322 & 0.8755 \\
\hline
\end{tabular}

In summary, the single Granger reasons for the daily rate of return $\mathrm{CH} 1$ in the Chinese stock market are: Indonesian stock market daily rate ID1 and Israeli stock market daily rate IL, which can be explained by the national political situation. The daily yield $\mathrm{CH} 1$ of the Chinese stock market is the single Granger cause of the daily yield MY1 of the Malaysian stock market. The Singapore stock yield SG1 is neither a reason for
Granger in the Chinese market nor a reason why the Chinese stock market $\mathrm{CH} 1$ is not the Singapore stock market SG1 Granger.

Next, we use $\mathrm{CH}$ as the response variable to perform prediction error variance decomposition. The result of the calculation is as follows:

TABLE VI. PREDCTION ERROR VARIANCE DECOMPOSITION

\begin{tabular}{|c|c|c|c|c|c|c|c|c|c|c|c|}
\hline CH1 & CZ1 & EG1 & HU1 & IN1 & ID1 & PL1 & RU1 & SA1 & TH1 & gu & VN1 \\
\hline 100 & 0 & 0 & 0 & 0 & 0 & 0 & 0 & 0 & 0 & 0 & 0 \\
\hline 86.96 & 0.031 & 4.475 & 0.181 & 0.019 & 1.318 & 0.362 & 0.007 & 0.682 & 0.814 & 3.651 & 1.495 \\
\hline 74.40894 & 2.474894 & 4.653662 & 0.822339 & 0.33189 & 4.648254 & 0.786666 & $\begin{array}{l}0.02159 \\
7\end{array}$ & 1.631578 & 5.217544 & 3.698085 & 1.304552 \\
\hline 71.11696 & 2.377984 & 4.602546 & 2.72107 & 0.501728 & 4.452738 & 1.017858 & 0.10656 & 2.345286 & 5.277484 & 3.616006 & 1.863784 \\
\hline 69.70829 & 2.437789 & 4.542229 & 2.677155 & 0.493124 & 4.484404 & 1.183858 & 0.10784 & 2.628576 & 5.583919 & 4.097602 & 2.055211 \\
\hline
\end{tabular}




\begin{tabular}{|c|c|c|c|c|c|c|c|c|c|c|c|}
\hline 69.10652 & 2.553242 & 4.621268 & 2.657684 & 0.712029 & 4.613865 & 1.184852 & $\begin{array}{l}0.12799 \\
1\end{array}$ & 2.660016 & 5.538915 & 4.143729 & 2.079893 \\
\hline 68.69244 & 2.538357 & 4.602754 & 2.664769 & 1.001428 & 4.617166 & 1.245213 & 0.12759 & 2.701548 & 5.532901 & 4.144692 & 2.131139 \\
\hline 68.57429 & 2.537109 & 4.594385 & 2.659523 & 1.08266 & 4.632645 & 1.263358 & $\begin{array}{l}0.12799 \\
5\end{array}$ & 2.74083 & 5.522397 & 4.136869 & 2.12794 \\
\hline 68.5416 & 2.541406 & 4.594534 & 2.684125 & 1.082181 & 4.630256 & 1.262864 & $\begin{array}{l}0.12875 \\
1\end{array}$ & 2.745229 & 5.519578 & 4.134924 & 2.134549 \\
\hline 68.50087 & 2.545819 & 4.593054 & 2.683078 & 1.101635 & 4.649811 & 1.26903 & $\begin{array}{l}0.12962 \\
4\end{array}$ & 2.743917 & 5.516454 & 4.132515 & 2.134194 \\
\hline
\end{tabular}

The prediction of $\mathrm{CH} 1$ for the first phase of the forecast is entirely based on its own variance; even if it is forecasted forward for 10 periods, there are $68.5 \%$ of the variance of the prediction from itself, $5.12 \%$ from TH1, and $4.65 \%$ from ID1. $4.593 \%$ came from EG1, the lowest impact was RU1, followed by IN.

It is not difficult to find that there are three influencing factors in the degree of its effect. One is the geographical distance. Thailand is closer to China and therefore has a greater impact. The second is the degree of development of the national stock market. The stock market in India is less developed and thus has a lower degree of influence; the third is the number of countries. Russia has a small population and its stock market is less affected.

\section{CONCLUSION}

This article has conducted an in-depth study on the linkage between China and the daily returns of the stock markets of 17 countries from Southeast Asia, South Asia, West Asia, North Africa, and Central and Eastern Europe. Based on the stock market indices of 18 countries including the Shanghai Composite Index, the Prague Composite Index, the Egyptian CMA Index, and the Budapest Stock Market Index, the article uses the natural logarithm to calculate the daily returns of the country's stock indexes. Through the statistical descriptive test and ADF test of the daily returns of stock indexes in 18 countries, the daily yield ratio of the Shanghai stock index is co-integrated with other countries, Granger causality test, and finally the prediction error variance decomposition is performed. The conclusion is:

(1) In the income sequence of the 18 countries' stock market indices, except for Hungary, Philippines, Russia, Saudi Arabia, Turkey, UAE, and other countries, the other countries are all left-biased; the returns of all stock indexes are characterized by "spikes". Except for India, Indonesia, and Russia, the return rates of stock indexes in other countries do not obey the assumption of normal distribution; the ADF test shows that there are no unit roots in all the sequences, that is, they are all stable; in the cointegration test, Lebanon, the Philippines The three countries in the United Arab Emirates failed to pass the cointegration test on the return of OLS; the residue series of the OLS regression performed by the stock markets of other countries and the yield of the Shanghai Composite Index were able to pass the ADF test, proving the return rates of the other 14 countries and the Shanghai Composite Index. There is indeed a co-integration relationship; Granger causality test results show that Indonesian and Israeli stock market returns are single Granger causes for Chinese stock market yields; Chinese stock market yields are single Granger causes for Malaysian yield; Singapore Not the Granger cause of China's stock market yield, China's stock market gains It is not Granger's reason for the Singapore stock market's yield; 'The prediction error variance decomposition results show that in addition to its strong reaction to itself, compared to other countries, the Shanghai stock market's response rate to the Thai stock market's rate of return has been relatively The high level, followed by Egypt, Indonesia, Turkey and other countries, and Russia's impact on China's stock market has the least impact.

(2) There is indeed a linkage between China's Shanghai stock market yield and the countries from "The Belt and Road" , and because of geographical location, the linkage between Thailand and China's stock market is the strongest, and between Russian and Chinese stock market yields. The linkage is the weakest; secondly, due to the different degree of development of the national stock market, the impact of the Indian stock market on the return rate of the Chinese stock market is relatively small; in addition, the linkage is also affected by the political situation of a country, such as Israel. In the co-integration test, Israel cannot pass the co-integration 
test, which has a certain connection with the turbulent political situation in the country.

\section{ACKNOWLEDGMENT}

This paper is sponsored by the Foundation for Talent Introduction Project of Yunnan University of Finance and Economics (Grant No.80059900194).

\section{REFERENCES}

[1] K. Forbes, and M. China, "A Decomposition of Global Linkages in Financial Markets over Time", Review of Economics and Statistics,2004,pp.705-722.
[2] A. Bonfiglioli. and C. Favero, "Explaining Co- movements between Stock Markets: The Case of US and Germany", Journal of International Money and Finance, 2005,vol.24,pp.1299-1316.

[3] M. Ehrmann., M. Fratzscher and A. Mehl, "What has Made the Current Financial Crisis Truly Global?" Mimeo, European Central Bank, 2009.

[4] J.J. Wang F. Zhu and F. F. Dou, "Who plays the Key Role among Shanghai, Shenzhen and Hong Kong Stock Market?" China and World Economy, 2012, pp.102-120.

[5] C. Stark, Diversifying In The Integrated Markets Of Asean+3 [M] Diversifying in the Integrated Markets of ASEAN+3. LAPLAMBERT Academic Publishing, 2010

[6] M. Madaleno, and C. Pinho, "International Stock

Market Indices Comovements: A New Look", International Journal of Finance and Economics, 2011, vol.16, pp.632-639. 